\title{
GERMINATION, INITIAL GROWTHAND COTYLEDON PROTEIN CONTENT OF BEAN CULTIVARS UNDER SALINITY STRESS ${ }^{1}$
}

\author{
BÁRBARAFRANÇADANTAS², LUCIANADE SÁ RIBEIRO3, CARLOSALBERTOARAGÃO ${ }^{4}$
}

\begin{abstract}
Excess salts in the root zone inhibit water uptake by plants, affect nutrient uptake and may result in toxicities due to individual salts in the soil solution. Excess exchangeable sodium in the soil may destroy the soil structure to a point where water penetration and root aeration become impossible. Sodium is also toxic to many plants. Beans (Phaseolus vulgaris L.) are consumed as protein source in northeastern Brazil, although little is known about common bean cultivar tolerance to salinity. The germination of bean cultivars under salt stress was studied. The cultivars 'Carioca' and 'Mulatinho' were submitted to germination test in a germinator at $25^{\circ} \mathrm{C}$, at the Seed Analysis Laboratory of the Brazilian Agricultural Research Corporation unit in the Semi- Arid region (Embrapa Semi Árido), Petrolina, Pernambuco State. These seeds were germinated on "germitest" papers imbibed in distilled water or in 10, 50, 100 e 200 mol.m$^{-3}$ sodium chloride (NaCl) solutions. At the first and second counts of the germination test, normal seedlings were counted, measured, weighed and dried, supplying data for vigor, total germination, fresh matter weight and dry matter weight and seedlings length. Total protein was quantified in cotyledons at 3, 6 and 9 days after sowing. The results indicated that the $\mathrm{NaCl}$ content influenced seed germination and concentrations above 50 mol. $\mathrm{m}^{-3}$ decreased germination and seedling growth.
\end{abstract}

Index terms: Phaseolus vulgaris, vigor, sodium chloride.

\section{GERMINAÇÃO, CRESCIMENTO INICIAL E TEOR DE PROTEÍNA NOS COTILÉDONES DE FEIJÃOEMESTRESSE SALINO}

RESUMO- O excesso de sais no sistema radicular inibe a absorção de água, absorção de nutrientes e pode resultar em toxicidade de alguns sais dissolvidos na solução do solo. Excesso de sódio trocável no solo pode destruir a estrutura do solo a um ponto em que a penetração de água e a aeração das raízes se tornam impossível. Além disso, o sódio é tóxico a muitas plantas. Feijão (Phaseolus vulgaris L.) é consumido como fonte de proteínas no nordeste do Brasil, no entanto pouco se sabe sobre a tolerância desses feijões à salinidade. Este trabalho objetivou o estudo da germinação de sementes e crescimento inicial de plântulas de duas cultivares de feijão ao estresse salino. As cultivares ‘Carioca'e 'Mulatinho' foram submetidas ao teste de germinação em germinador a $25^{\circ} \mathrm{C}$, no Laboratório de Análises de Sementes da Embrapa Semi Árido, Petrolina, Pernambuco. As sementes germinaram em papel "germitest" embebido em água destilada ou em soluções de cloreto de sódio ( $\mathrm{NaCl}$ ) nas concentrações de 10, 50, 100 e $200 \mathrm{~mol}^{-3}{ }^{-3}$. Na primeira e segunda contagens do teste de germinação as plântulas normais foram contadas, medidas, pesadas e secadas, obtendo-se dados de vigor e germinação total, massa de matéria fresca e seca, e comprimento de plântulas. O teor de proteínas totais foi quantificado em cotilédones aos 3, 6 e 9 dias após semeadura. Os resultados indicam que ao teor de $\mathrm{NaCl}$ influenciou na germinação e que concentrações acima de $50 \mathrm{~mol} . \mathrm{m}^{-3}$ inibiram a germinação e o crescimento das plântulas.

Termos para indexação: Phaseolus vulgaris, vigor, cloreto de sódio.

\footnotetext{
${ }^{1}$ Submetido em 30/11/2005. Aceito para publicação em 21/02/2007.

${ }^{2}$ Pesquisadora, Embrapa Semi-Árido C.P. 23, 56300-970, Petrolina-PE; barbara@cpatsa.embrapa.br
}

\footnotetext{
${ }^{3}$ Bióloga, UPE /Faculdade de Formação de Professores de Petrolina-PE; ${ }^{4}$ Professor Adjunto, UNEB/ Departamento de Tecnologia e Ciências Sociais, Juazeiro-BA
} 


\section{INTRODUCTION}

Salinization of agricultural soils is a worldwide concern, especially in irrigated lands, where water is the salttransporting agent through the soil profile. Saline soils present unfavorable conditions for seed germination and plant growth, limiting agricultural production. Irrigation induces an accumulation of salts at soil surface (Klar, 1984). Soil salinization affects germination, plant stand, plant vegetative development, productivity and, in the worst cases, causes plant death (Silva and Pruski, 1997). The effects of soluble salts are high osmotic pressure and toxic action of $\mathrm{Na}^{+}$and $\mathrm{Cl}^{-}$, which induces physiological disturbances and plant death.

In Brazil, salinity generally occurs in alkaline soils of the northeastern semi-arid region (Barbosa, 1996). The climate and soil conditions in the irrigated agriculture region of JuazeiroPetrolina are favorable to soil salinization processes, limiting crop production.

Several studies have been carried out to elucidate the salinity adaptation mechanisms (Silva et al. 1992). One of the most widespread methods of determining plant tolerance to salts is the germination percentage in salt solutions. Germination evaluation of salt treated and control seeds is used as an indicator of the tolerance of some species and cultivars to salinity. As well as germination and vigor tests, it is useful to evaluate the seeds physiological quality during salt stress. These evaluations are important to estimate the performance potential of the seeds in the field in salt stressing environments.

Beans species, such as the cowpea (Vigna unguiculata (L.) Walp), pigeon pea (Cajanus cajan (L.) Mills.) and common bean (Phaseolus vulgaris (L.) ), are the most important constituents of the Brazilian diet, due to their high protein level, good carbohydrate content and a great source of iron (Borém and Carneiro, 1999). Brazil is the second world Phaseolus bean producer and the first in the Phaseolus vulgaris species. The common bean is the most consumed per capita bean in Brazil about 20.3kg.year ${ }^{-1}$, equivalent to 56g.day ${ }^{-1}$ (Borém and Carneiro, 1999).

The bean cultivars show a large variability in their tolerance to several stress factors, such as salinity, drought and high temperatures and some morpho-physiological and biochemical traits are involved in offering tolerance mechanisms to these stresses (Moreno-Limon et al., 2000).

This study aimed to evaluate seed germination, seedling growth and biochemical modifications in two common bean cultivars, at different salt concentrations.

\section{MATERIAL AND METHODS}

The experiment was carried out at the Seed Analysis Laboratory of the Brazilian Agricultural Research Corporation unit in the Semi- Arid region (Embrapa Semi Árido), at Petrolina, Pernambuco State. Four replications of 50 seeds of the common bean (Phaseolus vulgaris L.) cultivars 'Carioca' and 'Mulatinho' were submitted to the germination test in a germinator at $25^{\circ} \mathrm{C}$, according to a totally randomized design. These seeds germinated on "germitest" papers imbibed in distilled water $\left(\mathrm{H}_{2} \mathrm{O}_{\mathrm{d}}\right)$ or in sodium chloride $(\mathrm{NaCl})$ solutions at a proportion of 2.5 times the weight of the paper (Menezes et al., 1993). The $\mathrm{NaCl}$ concentrations were 10, 50, 100 and 200 mol.m ${ }^{-3}$, whose electrical conductivity $\left(\mathrm{EC},{\mathrm{S} . \mathrm{m}^{-1}}^{-1}\right.$ ) was measured with a conductivity meter and the osmotic potential (Y, MPa) was calculated according to Vijayan (2003).

The evaluations were carried out according to the Rules for Seed Analysis (Brasil, 1992) at the first and second count, after 5 and 9 days and the data were assessed for percentage of normal seedlings. After germination evaluations, 10 normal seedlings were oven dried at $65^{\circ} \mathrm{C}$, for 72 hours, and weighed, determining the dry matter weight (DM). The fresh matter weight (FM) was also assessed before drying the seedlings (Nakagawa, 1999).

The seedling growth evaluation was according to Nakagawa (1999). Ten seeds were distributed along a line drawn longitudinally at $100 \mathrm{~mm}$ from the upper border of the germination paper pre-imbibed in the $\mathrm{NaCl}$ and $\mathrm{H}_{2} \mathrm{O}_{\mathrm{d}}$ solutions mentioned above, except for the $200 \mathrm{~mol} . \mathrm{m}^{-3} \mathrm{NaCl}$ solution. Paper rolls were similar to the germination test (Brasil, 1992). After 9 days in a $25^{\circ} \mathrm{C}$ germinator, the shoot length (SL) and root length (RL) were measured. The total seedling length (TL) and the RL:SL ratio were calculated from these data.

Total protein content in the seedling cotyledons was obtained from 3, 6 and 9 days germinated seedlings. The cotyledons were macerated in a $50 \mathrm{~mol} . \mathrm{m}^{-3}$ potassium phosphate buffer, $\mathrm{pH} 7.0$ and centrifuged at $5000 \mathrm{xg}$ for 10 minutes. The proteins were quantified according to Bradford (1976) using a casein reference curve.

The experimental data were statistically analyzed for means comparison using the Tukey test at $5 \%$ probability.

\section{RESULTS AND DISCUSION}

The electrical conductivity (CE) and the osmotic potential $(\mathrm{Y})$ of the solutions in which the seeds germinated as function of $\mathrm{NaCl}$ concentration are shown in Table 1. In many species 
these values are too high for water uptake and seed imbitition and germination (Murillo-Amador and Troyo-Diéguez, 2000). The results, however, reveal in the first count of the common bean seed germination test, that the vigor of the Mulatinho cultivar was higher than the Carioca cultivarstarting from the concentration of $\mathrm{NaCl} 10 \mathrm{~mol} . \mathrm{m}^{-3}$ and after that there was significant decrease in the vigor of the two cultivars. Although the Carioca cultivar control seeds presented higher germination percentage, the final germination of the Mulatinho cultivar overcame the salinity until the $100 \mathrm{~mol} . \mathrm{m}^{-3}$ concentration, whereas germination of the Carioca cultivar showed a significant decrease at $50 \mathrm{~mol} . \mathrm{m}^{-3}$ of $\mathrm{NaCl}$ (Table 2). According to Bernstein and Hayward (1958), an Y of -0.4MPa is required to reduce $50 \%$ beans growth. In this experiment the Ys were $0,-0.024,-0.122,-0.244$ and $-0.488 \mathrm{MPa}$ in order to increase the $\mathrm{NaCl}$ concentration, thus it is likely that the 100 and 200 mol. $\mathrm{m}^{-3} \mathrm{NaCl}$ concentrations inhibited seed germination.

The seedling growth can be represented by fresh and dry matter weight (FM and DM, respectively) and root, shoot and total seedlings length (RL, SL and TL, respectively). Regarding fresh and dry matter acumulation, the Carioca and Mulatinho cultivars presented improved FM and DM at the $\mathrm{NaCl}$ levels of 10 and $50 \mathrm{~mol} . \mathrm{m}^{-3}$ (Table 3).

According to Table 4, SL and RL were higher at 100 and $50 \mathrm{~mol} . \mathrm{m}^{-3}$, respectively, for both cultivars. On the other hand, the Carioca and Mulatinho common bean cultivars behaved differently regarding RL: SL and TL (Table 5). For Carioca cultivar seedlings RL:SL was higher at $100 \mathrm{~mol} . \mathrm{m}^{-3}$ and for Mulatinho cultivar seedlings it was higher in $\mathrm{H}_{2} \mathrm{O}_{\mathrm{d}}$ and TL increased with $10 \mathrm{~mol} . \mathrm{m}^{-3}$ in Carioca cultivar seedlings and in both cultivars TL differed from controls only at $100 \mathrm{~mol} . \mathrm{m}^{-3}$ Some authors affirm that low salt concentrations can act as primers improving germination and initial growth of many species by preventing membrane damage during imbibition (Sivritepe et al., 1999; Milligan et al., 2005).

Bean cotyledon total protein content was determined on

TABLE 1. NaCl concentration, electrical conductivity and the osmotic potential of the solutions in which the seeds germinated, as a function of NaCl concentration.

\begin{tabular}{ccc}
\hline $\mathrm{NaCl}$ concentration $\left(\mathrm{mol}_{\mathrm{m}}^{-3}\right)$ & Electrical conductivity $-\mathrm{EC}\left({\left.\mathrm{S} . \mathrm{m}^{-1}\right)}^{-1}\right.$ & Osmotic Potential - \\
\hline 0 & 0.000 & 0.000 \\
10 & 0.112 & -0.024 \\
50 & 0.448 & -0.122 \\
100 & 1.023 & -0.244 \\
200 & 1.874 & -0.488 \\
\hline
\end{tabular}

TABLE 2. First counting and total germination of seed of common bean cultivars Carioca and Mulatinho submitted to salt stress.

\begin{tabular}{|c|c|c|c|c|}
\hline \multirow{2}{*}{$\begin{array}{c}\mathrm{NaCl} \text { concentration } \\
\left(\mathrm{mol} . \mathrm{m}^{-3}\right)\end{array}$} & \multicolumn{2}{|c|}{ First counting (\% normal seedlings ) } & \multicolumn{2}{|c|}{ Total germination ( $\%$ normal seedlings) } \\
\hline & Carioca & Mulatinho & Carioca & Mulatinho \\
\hline 0 & $65 \mathrm{aA}^{*}$ & $70 \mathrm{aB}$ & $91 \mathrm{aAB}$ & $83 \mathrm{aA}$ \\
\hline 10 & $67 \mathrm{bA}$ & 86 aA & $97 \mathrm{aA}$ & $95 \mathrm{aA}$ \\
\hline 50 & $38 \mathrm{bB}$ & $54 \mathrm{aC}$ & $77 \mathrm{aB}$ & 89 aA \\
\hline 100 & $2 \mathrm{bC}$ & $18 \mathrm{aD}$ & $78 \mathrm{aB}$ & $44 \mathrm{bB}$ \\
\hline 200 & $0 \mathrm{aC}$ & $0 \mathrm{aE}$ & $0 \mathrm{aC}$ & $0 \mathrm{aC}$ \\
\hline $\mathrm{CV}(\%)$ & \multicolumn{2}{|c|}{18.7} & \multicolumn{2}{|c|}{13.97} \\
\hline
\end{tabular}

* Same capital letters in the column and lower case letters in the line, do not differ statistically at 5\%.

TABLE 3. Fresh matter weight (FM) and dry matter weight (DM) seedlings of common bean cultivars Carioca and Mulatinho submitted to salt stress.

\begin{tabular}{ccccc}
\hline \multirow{2}{*}{$\begin{array}{c}\mathrm{NaCl} \text { concentration } \\
\left(\text { mol.m }^{-3}\right)\end{array}$} & \multicolumn{2}{c}{ FM $(\mathrm{mg})$} & \multicolumn{2}{c}{ DM (mg) } \\
\cline { 2 - 5 } & $1210.25 \mathrm{aB} *$ & $1964.75 \mathrm{aB}$ & $287.50 \mathrm{aAB}$ & Mulatinho \\
\hline 0 & $1486.75 \mathrm{bB}$ & $3670.75 \mathrm{aA}$ & $414.00 \mathrm{aA}$ & $148.75 \mathrm{bB}$ \\
50 & $3732.50 \mathrm{aA}$ & $3029.25 \mathrm{aAB}$ & $396.75 \mathrm{aA}$ & $377.75 \mathrm{aA}$ \\
100 & $1986.75 \mathrm{aB}$ & $1729.50 \mathrm{aB}$ & $236.00 \mathrm{aB}$ & $279.50 \mathrm{aAB}$ \\
\hline $\mathrm{CV}(\%)$ & \multicolumn{3}{c}{25.48} \\
\hline
\end{tabular}

* Same capital letters in the column and lower case letters in the line, do not differ statistically at 5\%. 
TABLE 4. Average shoot (SL) and root length (RL) in seedlings of common bean cultivars Carioca and Mulatinho submitted to salt stress.

\begin{tabular}{crcrc}
\hline \multirow{2}{*}{$\left.\begin{array}{c}\mathrm{NaCl} \text { concentration } \\
(\text { mol.m }\end{array}{ }^{-3}\right)$} & \multicolumn{2}{c}{$\mathrm{SL}(\mathrm{mm})$} & \multicolumn{2}{c}{ RL $(\mathrm{mm})$} \\
\cline { 2 - 5 } & Carioca & Mulatinho & Carioca & Mulatinho \\
\hline 0 & $80.7 \mathrm{aB} *$ & $72.5 \mathrm{aB}$ & $118.1 \mathrm{aB}$ & $126.9 \mathrm{aA}$ \\
50 & $110.7 \mathrm{aA}$ & $82.6 \mathrm{bAB}$ & $147.0 \mathrm{aA}$ & $122.4 \mathrm{bA}$ \\
10 & $109.2 \mathrm{aA}$ & $9.6 \mathrm{aA}$ & $104.5 \mathrm{aB}$ & $90.7 \mathrm{aB}$ \\
$\mathrm{CV}(\%)$ & $36.4 \mathrm{aC}$ & $3.9 \mathrm{aC}$ & $58.8 \mathrm{aC}$ & $50.5 \mathrm{aC}$ \\
\hline
\end{tabular}

* Same capital letters in the column and lower case letters in the line, do not differ statistically at $5 \%$.

TABLE 5. Root: shoot ratio (RL:SL) and total seedlings longth (TL) of common bean cultivars Carioca and Mulatinho submitted to salt stress.

\begin{tabular}{|c|c|c|c|c|}
\hline \multirow{2}{*}{$\begin{array}{l}\mathrm{NaCl} \text { concentration } \\
(\text { mol.m-3 })\end{array}$} & \multicolumn{2}{|c|}{ RL:SL } & \multicolumn{2}{|c|}{$\mathrm{TL}(\mathrm{mm})$} \\
\hline & Carioca & Mulatinho & Carioca & Mulatinho \\
\hline 0 & $1.54 \mathrm{bAB}$ & $2.00 \mathrm{aA}$ & $198.8 \mathrm{aB}$ & $199.4 \mathrm{aA}$ \\
\hline 10 & $1.37 \mathrm{aAB}$ & $1.56 \mathrm{aAB}$ & $257.8 \mathrm{aA}$ & $204.9 \mathrm{bA}$ \\
\hline 50 & $1.04 \mathrm{aB}$ & $1.07 \mathrm{aB}$ & $213.7 \mathrm{aB}$ & $186.2 \mathrm{bA}$ \\
\hline 100 & $1.76 \mathrm{aA}$ & $1.40 \mathrm{aB}$ & $95.2 \mathrm{aC}$ & $89.1 \mathrm{aB}$ \\
\hline CV (\%) & \multicolumn{2}{|c|}{19.57} & \multicolumn{2}{|c|}{8.64} \\
\hline
\end{tabular}

* Same capital letters in the column and lower case letters in the line, do not differ statistically at 5\%.

three occasions, at radicle protrusion (3 days after sowing, DAS), at first germination count (6 DAS) and at second germination count (9 DAS). Cotyledon protein content patterns during germination and initial growth were similar in both cultivars evaluated. In control germinating seeds, cotyledon protein content decreased during germination and initial growth, due to protein mobilization. However, under light salt stress $\left(10 \mathrm{~mol} . \mathrm{m}^{-3} \mathrm{NaCl}\right)$, the germinating seeds presented inverse behavior, increasing protein content 9 DAS for both cultivars. On the other hand, $100 \mathrm{~mol} . \mathrm{m}^{-3} \mathrm{NaCl}$ induced an increase in protein content at 6 DAS (Figure 1).

Under high water stress, some plants produce lowmolecular-weight substances in abundance that lower the solute potential, such as amino acids and polyamines. The lower solute potential would cause an overall drop in water potential, so that water would still move into the cells and restore turgor (Marvel, 2003). Camara et al. (2000) observed an increase in proline, arginine, g-amino butyric acid, alanine, glutamine and glutamate in maize calli subjected to $\mathrm{NaCl}$ concentrations higher than $100 \mathrm{~mol} . \mathrm{m}^{-3}$. Salinity modulates the production of selected groups of proteins named "salt stress proteins" (Dell' Aquila and Spada, 1993). These results suggested that the pattern of "salt stress proteins" synthesis or protein turnover is different, according to the $\mathrm{NaCl}$ concentration and salt stress duration.

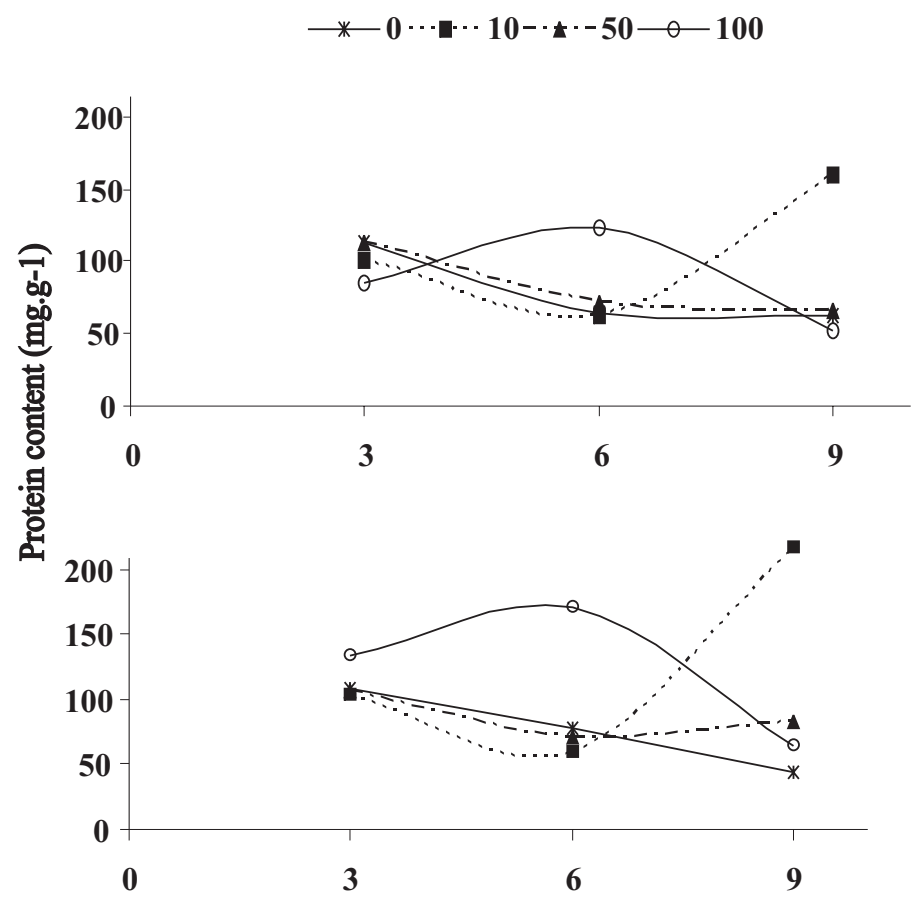

FIGURE 1. Protein content ( $\mathrm{mg} \mathrm{g}^{-1}$ of dry matter) in cotyledons of germinating bean seeds cv. Carioca (a) and Mulatinho (b) submitted to several salt concentrations ( $* 0, \square 10, \Delta 50$ and 0100 mol.m ${ }^{-3}$ of $\left.\mathrm{NaCl}\right)$. 


\section{CONCLUSIONS}

Salt concentrations higher than 50 and $100 \mathrm{~mol} . \mathrm{m}^{-3} \mathrm{NaCl}$ affected the germination speed and total germination, respectively, of bean seeds and seedling growth.

Bean seeds do not tolerate salt concentrations above 200 mol.m ${ }^{-3}$.

Protein content increases in cotyledons in salt stressed seedlings according to stress intensity and duration.

Seeds of the Carioca cultivar were more tolerant to salinity than the Mulatinho cultivar seeds.

\section{REFERENCES}

BARBOSA, C.D. Resposta de plantas jovens de algaroba (Propopis juliflora (Sw.) DC.) à salinidade. 1996. 28f. Monografia (Graduação em Agronomia) - Centro de Ciências Agrárias, Universidade Federal da Paraíba, Patos, 1996.

BERNSTEIN, L.; HAYWARD, H.E. Physiology of salt tolerance. Annual Review of Plant Physiology, Palo Alto, v.9, n.1, p.25-46, 1958.

BORÉM, A.; CARNEIRO, J.E.S. A cultura. In: VIEIRA, C.; PAULA JR., T.J.; BORÉM, A. (Ed.). Feijão: aspectos gerais e cultura no estado de Minas Gerais. Viçosa: UFV, 1999. p.13-17.

BRADFORD, M.M. A rapid and sensitive method for the quantitation of microgram quantities of protein utilizing the principle of protein-dye binding. Analytical Biochemistry, San Diego, v.72, n.1/2, p.248-254, 1976.

BRASIL. Ministério da Agricultura e da Reforma Agrária. Regras para análise de sementes. Brasília: SNDA/DNDV/CLAV, 1992. 365p.

CAMARA, T., R.; WILLADINO, L.; TORNÉ, J.M.; MANICK, A.; SANTOS, M.A. Effect of saline stress and exogenous proline in maize callus. Revista Brasileira de Fisiologia Vegetal, Londrina, v.12, n.2, p.146-155, 2000.

DELL'AQUILA A.; SPADA, P. The effect of salinity stress upon protein synthesis of germinating wheat embryos. Annals of Botany, Oxford, v.72, n.2, p. 97-101, 1993.

KLAR, A.E. Aágua no sistema solo-planta-atmosfera. São Paulo: Nobel, 1984. 408p.

MARVEL, S. Cellular and plant water relations. Available at: <http://www.lhup.edu/ smarvel/biol206/notes/Water 1.doc >. Accessed in 29 may. 2003.

MENEZES, N.L.; SILVEIRA, T.L.D.; STORK, L. Efeito do nível de umedecimento do substrato sobre a germinação de curcubitáceas. Ciência Rural, Santa Maria, v.23, n.2 p.157-160, 1993.

MILLIGAN, A.; TALBERT, S.; GATES, M. Salinity level and salt priming effects on Amaranth and Teff plant growth. Available at: <http://www.southwestern.edu/academic/biology/papers/files/ BF_report/BF_report_gat_tal_mil.pdf $>$. Acessed in 10 sep. 2005.

MORENO-LIMÓN, S.; MAITI, R.K.; FOROUGHBAKHCH, R. Genotypic variability in Phaseolus bean cultivars exposed to salinity at the germination stage. Crop Research, Hisar, v.19, n.1, p.487-492, 2000.

MURILLO-AMADOR, B.; TROYO-DIÉGUEZ, E. Effects of salinity on the germination and seedlings characteristics of cowpea [Vigna unguiculata (L.) Walp.]. Australian Journal of Experimental Agriculture, Quensland, v.40, n. 3, p.433-438, 2000.

NAKAGAWA, J. Testes de vigor baseados no desempenho das plântulas. In: KRZYZANOWSKI, F.C.; VIEIRA, R.D.; FRANÇANETO, J.B. (Ed.). Vigor de sementes: conceitos e testes. Londrina: ABRATES, 1999. p.2-1 - 2-24.

SILVA, D.; PRUSKI, F.F. Recursos hídricos e desenvolvimento sustentável da agricultura. Brasília: MMA/SBH/ABEAS, 1997. 252p.

SILVA, M.J.; SOUZA, J.G.; BARREIRO-NETO, M.; SILVA, J.V. Seleção de três cultivares de algodoeiro para tolerância a germinação em condições salinas. Pesquisa Agropecuária Brasileira, Brasília, v.27, n.4, p.655-659, 1992.

SIVRITEPE, H.; ERIS, A.; SIVRITEPE, N. The effect of NaCl priming on salt tolerance in melon seedlings. Acta Horticulturae, Leuven, v.492, n.1, p.77-84, 1999.

VIJAYAN, P. Definitions. Available at: < http://www.usask.ca/ biology/331/notes/B331lectur10.htm>. Accessed in 11 jun. 2003. 